Article

\title{
Effect of Particle Size on the Corrosion Behaviour of Gold in the Presence of Chloride Impurities: An EFC-ICP-MS Potentiodynamic Study
}

\author{
Primož Jovanovič ${ }^{1, *}$, Martina Može ${ }^{2}$, Ema Gričar ${ }^{2}$, Martin Šala ${ }^{3}$, Francisco Ruiz-Zepeda ${ }^{4}$ (D, \\ Marjan Bele ${ }^{4}$, Gregor Marolt ${ }^{2}$ and Nejc Hodnik 1,*(D) \\ 1 Department of Catalysis and Chemical Reaction Engineering, National Institute of Chemistry, Hajdrihova 19, \\ SI-1000 Ljubljana, Slovenia \\ 2 Faculty of Chemistry and Chemical Technology, University of Ljubljana, 113 Večna pot, SI-1000 Ljubljana, \\ Slovenia; moze.martina@gmail.com (M.M.); ema.gricar@fkkt.uni-lj.si (E.G.); gregor.marolt@fkkt.uni-lj.si (G.M.) \\ 3 Department of Analytical Chemistry, National Institute of Chemistry, Hajdrihova 19, SI-1000 Ljubljana, Slovenia; \\ martin.sala@ki.si \\ 4 Department of Materials Chemistry, National Institute of Chemistry, Hajdrihova 19, SI-1000 Ljubljana, Slovenia; \\ Francisco.RuizZepeda@ki.si (F.R.-Z.); marjan.bele@ki.si (M.B.) \\ * $\quad$ Correspondence: primoz.jovanovic@ki.si (P.J.); nejc.hodnik@ki.si (N.H.); Tel.: +386-1-4760-537 (P.J. \& N.H.)
}

Received: 5 December 2018; Accepted: 21 December 2018; Published: 25 December 2018

\begin{abstract}
A profound understanding of the Au dissolution process is a prerequisite for optimal utilization of Au-based materials. This goes for either increasing the corrosion stability of materials in the sectors where the long-term functionality of $\mathrm{Au}$ is needed or decreasing the corrosion stability where the recovery of the Au component is crucial. By employing an extremely sensitive online analytical system, consisting of an electrochemical flow cell coupled to an inductively coupled plasma mass spectrometry, in situ potential-resolved dissolution of $\mathrm{Au}$ in the $\mathrm{ppb}$ range is enabled. A comparative study of two $\mathrm{Au}$ based materials, (i) a polycrystalline Au disk and (ii) carbon-supported Au nanoparticles, is presented. As a probe, chloride ions were used to elucidate the distinct differences in the corrosion behavior of the two analogues.
\end{abstract}

Keywords: gold; corrosion; electrochemistry; dissolution; chlorides; nanoparticles; EFC-ICP-MS

\section{Introduction}

Due to its nobility, gold is one of the most frequently used metals in applications where corrosion stability is needed (e.g., jewelry, electrical contacts, bio-medical applications, etc.) [1]. This is especially popular in the field of electrochemistry, namely, electrochemical sensorics [2-4] and electrocatalysis [5-15] where gold is frequently used. Furthermore, gold is also commonly used as a working or counter electrode in conventional electrochemical setups. In order to elucidate the adequacy of gold-based materials under harsh electrochemical conditions, fundamental insight into Au corrosion is urgently needed. At the same time, understanding corrosion may be of great importance in the hydrometallurgical steps of gold from end-of-life devices in the recycling process. This is of special importance in waste electrical and electronic equipment (WEEE), where Au is used in integrated circuits. Recently, also printing of gold nanoparticles has been gaining popularity [16-18]. It has been shown that these devices can fail in operation due to corrosion of $\mathrm{Au}$ [19]. This can be triggered by even trace amounts of halogenides, 
such as chloride [20]. Overall, a profound understanding of the electrochemical dissolution of Au enabling qualitative, as well as quantitative data, was already recognized half a century ago when Au corrosion in the presence of chlorides was studied [21]. Owing to the penetration of online analytical tools for the purposes of corrosion investigations, a deeper understanding of noble material dissolution has recently been enabled [22-29]. We present an investigation of electrochemical dissolution process of polycrystalline gold in the presence of complexing chloride anions in a wide concentration range. For this purpose, well-established online analytics consisting of an electrochemical flow cell coupled to inductively coupled plasma mass spectrometry (EFC-ICP-MS) has been employed [7,28-32].

\section{Materials and Methods}

\subsection{Au/C Synthesis}

Gold nanoparticles on carbon were prepared by dissolving $0.3 \mathrm{mmol}$ of hydrogen tetrachloroaurate(III) hydrate (abcr GmbH, Karlsruhe, Germany) and 0.45 mmol of citric acid (Sigma-Aldrich, St. Louis, MO, USA) in $0.6 \mathrm{~mL}$ of water. The solution was then mixed with $0.15 \mathrm{~g}$ of carbon black (VULCAN XC72R, Cabot Corporation, Alpharetta, GA, USA) at $50{ }^{\circ} \mathrm{C}$ until evaporation. Afterward, the mixture was thermally treated in $5 \% \mathrm{H}_{2} / \mathrm{Ar}$ mixture. The temperature was increased with a rate of $5{ }^{\circ} \mathrm{C} \cdot \mathrm{min}^{-1}$ to $500{ }^{\circ} \mathrm{C}$ for $3 \mathrm{~h}$. Then the sample was cooled to room temperature with a rate of $3{ }^{\circ} \mathrm{C} \cdot \mathrm{min}^{-1}$. After thermal treatment the sample contained $30 \mathrm{wt} \%$ of gold nanoparticles.

\subsection{Transmission Electron Microscopy}

Au nanoparticles were analyzed by scanning transmission electron microscopy (STEM, JEOL Ltd., Tokyo, Japan). A JEOL ARM CF operated at $80 \mathrm{kV}$ was used.

\subsection{Electrochemical Measurements}

The first set of experiments was performed in a conventional three-electrode glass cell. All the electrodes were placed in the same compartment. Either (1) Au disk electrode $(d=3 \mathrm{~mm})$ or (2) glassy carbon electrode (GC, $d=5 \mathrm{~mm}$ ) coated with Au nanoparticles $(\mathrm{Au} / \mathrm{C})$ were used as a working electrode, $\mathrm{Pt}$ rod as a counter electrode and $\mathrm{Ag} / \mathrm{AgCl}$ as a reference electrode. $\mathrm{Au} / \mathrm{C}$ was synthesized as described above; $20 \mu \mathrm{L}$ of water suspension (1 mg Au/C per $1 \mathrm{~mL}$ water) was drop-casted on the surface of GC disk. Prior to each experiment, the electrochemical cell was boiled in Milli-Q water for $1 \mathrm{~h}$, and the electrode was polished to mirror finish with $\mathrm{Al}_{2} \mathrm{O}_{3}$ paste (particle size $0.05 \mu \mathrm{m}$, Buehler, Lake Bluff, IL, USA) on a polishing cloth (Buehler). After polishing, the electrodes were rinsed and ultrasonicated (Ultrasound bath Iskra Sonis 4, Iskra Pio Ltd., Šentjernej, Slovenia) in Milli-Q water for $5 \mathrm{~min}$. Electrochemical experiments were performed under ambient conditions. Different amounts of $\mathrm{HCl}$ were added to the electrolyte in order to prepare $10^{-6}, 10^{-5}, 10^{-4}, 10^{-3}$ and $10^{-2} \mathrm{M}$ solutions of $\mathrm{Cl}^{-}$in $0.05 \mathrm{~mol} \cdot \mathrm{L}^{-1} \mathrm{H}_{2} \mathrm{SO}_{4}$.

A second set of electrochemical experiments was conducted in an electrochemical flow cell which was coupled with an ICP-MS setup (EFC-ICP-MS) already introduced in our previous publications [7,28-32]. Shortly, commercial BASi electrochemical flow cell (Cross-Flow Cell Kit MW-5052) with a homemade silicon gasket of $1 \mathrm{~mm}$ thickness was coupled with an Agilent 7500ce ICP-MS instrument (Agilent Technologies, Palo Alto, CA, USA) equipped with a MicroMist glass concentric nebulizer and a Peltiercooled Scott-type double-pass quartz spray chamber. A forward radio frequency power of $1500 \mathrm{~W}$ was used with $\mathrm{Ar}$ gas flows: carrier $0.85 \mathrm{~L} \cdot \mathrm{min}^{-1}$, makeup $0.28 \mathrm{~L} \cdot \mathrm{min}^{-1}$, plasma $1 \mathrm{~L} \cdot \mathrm{min}^{-1}$, and cooling $15 \mathrm{~L} \cdot \mathrm{min}^{-1}$. $0.05 \mathrm{~mol} \cdot \mathrm{L}^{-1} \mathrm{H}_{2} \mathrm{SO}_{4}$ (Aldrich $96 \%$, 99.999\% trace metals basis) acid was used as electrolyte carrier medium. Different amounts of $\mathrm{HCl}$ were added to the electrolyte in order to prepare $10^{-6}, 10^{-5}, 10^{-4}$ and $10^{-3}$ solutions of $\mathrm{Cl}^{-}$in $0.05 \mathrm{~mol} \cdot \mathrm{L}^{-1} \mathrm{H}_{2} \mathrm{SO}_{4}$. Solutions were pumped through the electrochemical 
cell at $150 \mu \mathrm{L} \cdot \mathrm{min}^{-1}$ using a syringe pump (WPI sp100i, World Precision Instruments, Sarasota, FL, USA). The electrochemical cell is based on a three-electrode configuration setup. Two cases were investigated: (1) the working electrode consisted of two Au polycrystalline disks $(d=3 \mathrm{~mm})$ and (2) of two glassy carbon disks ( $3 \mathrm{~mm}$ in diameter). In each case, one of them was modified by drop-casting a suspension of $\mathrm{Au}$ nanoparticles supported on carbon $(\mathrm{Au} / \mathrm{C})$. Stainless steel housing was used as the counter electrode and $\mathrm{Ag} / \mathrm{AgCl}$ was used as a reference electrode.

In both electrochemical cells (conventional glass cell and electrochemical flow cell) electrochemical treatment consisted of 200 cyclovoltammetry cleaning cycles between $0.05-1.2 \mathrm{~V}\left(300 \mathrm{mV} \cdot \mathrm{s}^{-1}\right)$ followed by slow potentiodynamic $\left(20 \mathrm{mV} \cdot \mathrm{s}^{-1}\right)$ sequences by gradually increasing the upper potential limit (UPL). The highest UPL in this work was set to $1.6 \mathrm{~V}$ vs. RHE in order to avoid the formation of oxygen bubbles due to oxygen evolution reaction (OER) or the oxidation of GC electrodes in the case of Au nanoparticles. Au real surface area was estimated by integrating the charge under the voltammetric profile in a cathodic direction in an EFC configuration (Au oxide reduction). Here, the assumption was made that at the Burshtein minimum, the electrode is covered by one monolayer of adsorbed oxygen with a transferred charge of $400 \mu \mathrm{C} \cdot \mathrm{cm}^{-2}$. Although this is not completely accurate, it is still a good approximation that enables us to compare two samples. All potentials are referred to reversible hydrogen electrode (RHE).

\section{Results}

\subsection{Structural Characterization of Au/C Nanoparticles Composite}

The majority of the particles exhibited an irregular shape, and mostly a size range below $5 \mathrm{~nm}$ (Figure 1a). The irregular shape of the particles can be described as sharp shattered crystallites that are well distributed on the carbon support. In addition, some very small clusters were also present, as can be observed in Figure 1a. However, the platonic polyhedral shapes, commonly observed in noble metal crystals, were also observed in the analyzed Au nanoparticles, ranging in size from 10 to $15 \mathrm{~nm}$. In Figure 2a, a truncated icosahedron is shown displaying planes with an interplanar distance of $2.3 \AA$ corresponding to $\{111\}$ lattice planes of Au. Therefore this sample can be considered as a typical representative of gold nanoparticles.
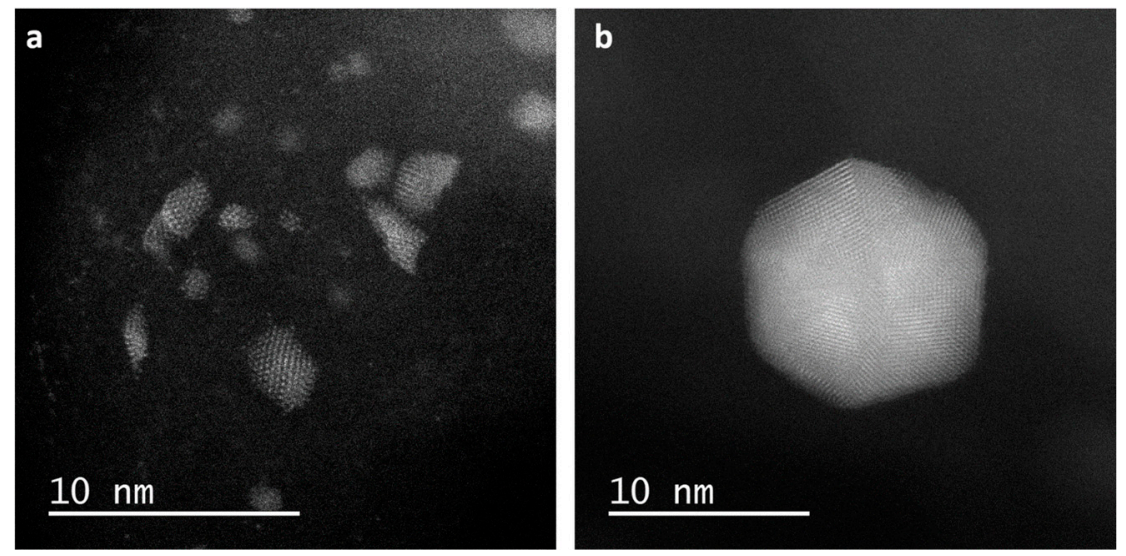

Figure 1. Scanning transmission electron microscope (STEM) high-angle annular dark field images of gold nanoparticles: (a) Irregular shape; (b) Polyhedral shape (truncated icosahedron). 

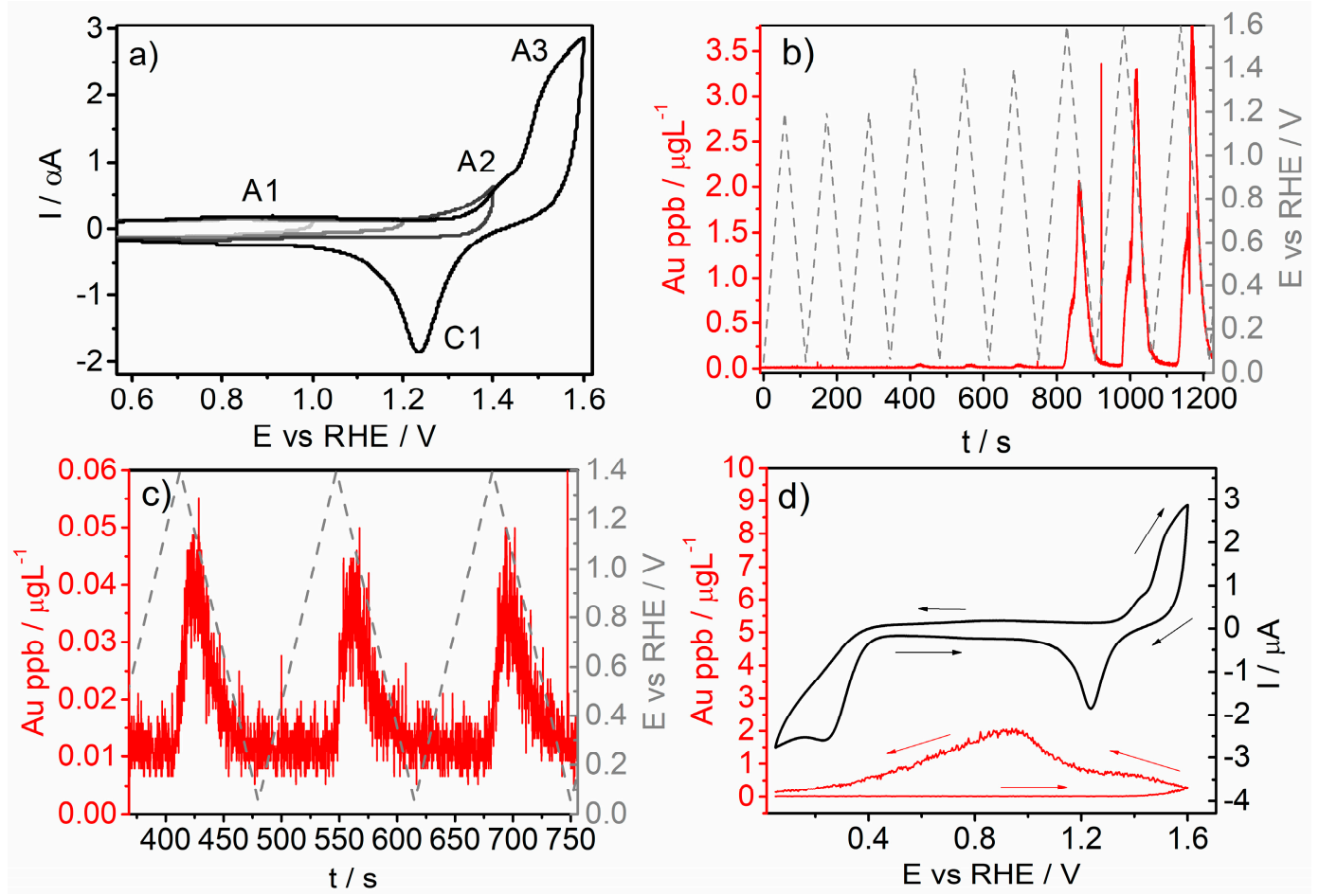

Figure 2. (a) Cyclovoltammetric $\left(20 \mathrm{mV} \cdot \mathrm{s}^{-1}\right)$ response of Au polycrystalline disc by gradually increasing the upper potential limit for $200 \mathrm{mV}$ from $1 \mathrm{~V}$ to $1.6 \mathrm{~V}_{\mathrm{RHE}}$ in $0.05 \mathrm{M} \mathrm{H}_{2} \mathrm{SO}_{4}$ in a conventional three-electrode cell; (b,c) Electrochemical flow cell coupled to inductively coupled plasma mass spectrometry (EFC-ICP-MS) measurements of Au dissolution from Au polycrystalline disc during potentiodynamic cycles $\left(20 \mathrm{mV} \cdot \mathrm{s}^{-1}\right.$, 0.05-1.4 or 1.6 $\mathrm{V}_{\mathrm{RHE}}$ ) in $0.05 \mathrm{M} \mathrm{H}_{2} \mathrm{SO}_{4}$; (d) Simultaneous presentation of Au dissolution profile and current signal during the potentiodynamic cycle $\left(20 \mathrm{mV} \cdot \mathrm{s}^{-1}, 0.05-1.6 \mathrm{~V}_{\mathrm{RHE}}\right)$.

\subsection{Electrochemical Dissolution of Polycrystalline Au Disk}

\subsubsection{Dissolution of Polycrystalline Au Disk in the Absence of Chlorides}

A series of cyclovoltammetry potential sweeps with increasing UPL and a scan rate of $20 \mathrm{mV} \cdot \mathrm{s}^{-1}$ was applied to the gold electrode in a conventional rotating disc electrode (RDE) configuration in the absence and presence of chloride impurities. Characteristic Au redox features frequently referred to as a fingerprint, are visible (Figure 2a). These characteristics are similar to those described in the literature $[21,27,33,34]$. We note that some discrepancies of cyclic voltammograms (CV) of gold electrodes are expected. This is due to different electrode preparation $[35,36]$ that influences grain size, surface morphology, purity. Furthermore different polishing and cleaning and electrochemical activation procedures can lead to different cyclovoltammetry profiles as well. These can be described following the established mechanism of Au oxidation [37-39]. Namely, in the positive going sweep below $1.2 \mathrm{~V}$ vs. RHE, the surface of gold is covered by adsorbed supporting electrolyte anions (labeled as feature A1 in Figure 2a) whereas the coverage with hydroxo species on the other hand is relatively low. Above $1.2 \mathrm{~V}$ vs. RHE the adsorbed anions of the supporting electrolyte are getting displaced by adsorbed $\mathrm{OH}$ and $\mathrm{O}$ species (labeled as feature A2 in Figure 2a). At higher potentials, the formation of bulk oxide/hydroxide or hydrous oxide film takes place (labeled as feature A3 in Figure 2a) via the so-called place-exchange phenomena, that is, incorporation of $\mathrm{O}$ into the sub-surface layers [40]. Gold "oxide" film is electrochemically reduced in the cathodic scan (labeled as feature C1 in Figure 2a). 
More insights into electrochemical behavior is provided by combining the cyclovoltammetry and online dissolution profiles of Au. This is achieved by combining the so-called electrochemical flow cell with inductively coupled plasma mass spectrometry analytics (EFC-ICP-MS) [30,31,41,42]. This approach is especially appropriate to study such corrosion phenomena as it allows one to synchronize dissolution and current signal with the potential ramp (Figure 2d). In general potentiodynamically induced dissolution of noble metals can be described as transient phenomena [24,26,42,43]. Dissolution profiles, therefore, consist of anodic and cathodic counterparts. In the former, the dissolution is triggered by the formation of surface/subsurface oxides as indicated in Figure 3b,c where dissolution coincides well with the region of Au surface oxidation (A3) onset $[23,27]$. In the cathodic scan, reduction of the oxide is governing $\mathrm{Au}$ dissolution. In this case corrosion of metals is ascribed to the exclusion of oxide ions during reduction of oxides [24,44]. Both dissolution counterparts are clearly resolved when UPL of $1.6 \mathrm{~V}$ is reached, namely the less substantial anodic dissolution peak and dominating cathodic dissolution peak (Figure 2d). However, it has been shown that when Au is exposed to higher UPLs the anodic dissolution becomes the predominant component, whereas cathodic dissolution does not increase substantially $[23,27,45]$. In the case of UPLs used in this study, cathodic dissolution is the predominant dissolution counterpart, which is in line with several works on highly sensible dissolution measurements of $\mathrm{Au}[23,27,45,46]$. Although the predominant dissolution is transient, thermodynamic reactions still found in Pourbaix diagrams are in place (see below).
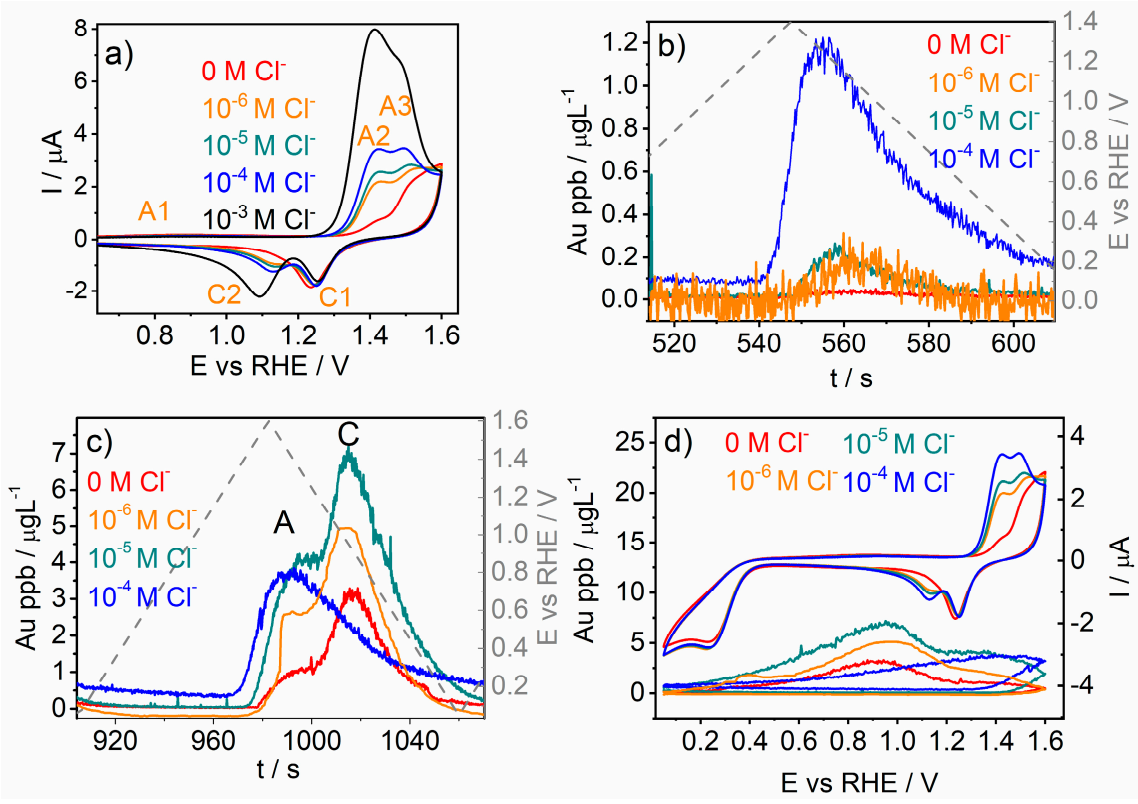

Figure 3. EFC-ICP-MS measurements of Au dissolution from Au polycrystalline disk in the absence $(\mathbf{a}, \mathbf{b})$ and presence of chlorides (c,d) during potentiodynamic cycles $\left(20 \mathrm{mV} \cdot \mathrm{s}^{-1}, 0.05-1.4\right.$ or $1.6 \mathrm{~V} \mathrm{RHE}_{\text {) }}$; (d) Simultaneous presentation of Au dissolution profile and current signal during potentiodynamic cycling $\left(20 \mathrm{mV} \cdot \mathrm{s}^{-1}, 0.05-1.6 \mathrm{~V}_{\mathrm{RHE}}\right)$.

Electrochemical reactions in the absence of chlorides:

$$
\begin{gathered}
2 \mathrm{Au}+3 \mathrm{H}_{2} \mathrm{O} \rightarrow \mathrm{Au}_{2} \mathrm{O}_{3}+6 \mathrm{H}^{+}+6 \mathrm{e}^{-} ; \\
E^{0}=1.457+0.0591 \log \left[\mathrm{H}^{+}\right] \\
\mathrm{Au}+3 \mathrm{H}_{2} \mathrm{O} \rightarrow \mathrm{H}_{3} \mathrm{AuO}_{3}+3 \mathrm{H}^{+}+3 \mathrm{e}^{-} \\
E^{0}=1.511+0.0591 \log \left[\mathrm{H}^{+}\right]
\end{gathered}
$$




$$
\begin{gathered}
\mathrm{Au} \rightarrow \mathrm{Au}^{3+}+3 \mathrm{e}^{-} \\
E^{0}=1.498+0.0197 \log \left[\mathrm{Au}^{3+}\right]
\end{gathered}
$$

Electrochemical reactions in the presence of chlorides:

$$
\begin{gathered}
\mathrm{Au}+2 \mathrm{Cl}^{-} \rightarrow \mathrm{AuCl}_{2}^{-}+\mathrm{e}^{-} ; \\
E^{0}=1.15-0.1183 \log \left[\mathrm{Cl}^{-}\right]+0.0592 \log \left[\mathrm{AuCl}_{2}^{-}\right] \\
\mathrm{Au}+4 \mathrm{Cl}^{-} \rightarrow \mathrm{AuCl}_{4}^{-}+3 \mathrm{e}^{-} ; \\
E^{0}=1.002-0.079 \log \left[\mathrm{Cl}^{-}\right]+0.0197 \log \left[\mathrm{AuCl}_{4}^{-}\right]
\end{gathered}
$$

\subsubsection{Dissolution of Au Polycrystalline in the Presence of Chlorides}

Comparison of characteristic CV features reveals that anodic features (A1 and A2) are completely absent (Figure 3a) when the concentration of chloride is sufficiently large $\left(\geq 10^{-4} \mathrm{M} \mathrm{Cl}^{-}\right)$. This indicates that chlorides are covering the surface of $\mathrm{Au}$, hence preventing or even shifting the formation of oxides to higher potentials. This is additionally supported by observing cathodic currents where a potential shift towards more anodic potentials corresponding to a reduction of Au oxides is clearly resolved in the presence of chlorides. Since less oxide is formed in the presence of chlorides, it results in lowered oxide reduction current in the cathodic scan (Figure 3a). The shift to anodic potentials is also in accordance with the literature, and means that lower overpotentials are needed to reduce the lesser amount of oxide [31,44]. Apart from that, chlorides are known to accelerate corrosion of Au via formation of several complexes that are thermodynamically more favored than the electrochemical dissolution of $\mathrm{Au}$ in the absence of chlorides (see Equations above). Therefore, an additional cathodic peak (C2) can be observed at a more negative potential on the $\mathrm{CV}$ of gold in the chloride-containing electrolyte, which is attributed to the re-deposition of dissolved gold species (Figure 3a) [47,48]. By increasing the concentration of chlorides, anodic current increase is clearly resolved (peak A2 and also A3 to a lesser extent in Figure 3a). The current increase is not attributed to the formation of gold oxide but due to direct gold dissolution (oxidation) into chloride complexes. Therefore, in general, observed anodic dissolution profiles in the presence of chloride impurities consist of "oxide-induced" dissolution (in the absence of chloride) and "chloride-induced" dissolution (in the presence of chlorides), where "oxide-induced" dissolution is inhibited. This is directly confirmed by the EFC-ICP-MS. Namely, a substantial increase in Au dissolution in comparison to the chloride-free electrolyte is detected already in the case of low concentrations of chlorides and low UPL (Figure 3b). Under these potentials, "oxide-induced" dissolution is significantly less intensive (Figure 3b, red curve) as a low amount of oxide is formed (see CVs in Figure 2a). In the case of higher UPL both, anodic (labeled as A) and cathodic dissolution (labeled as C) counterparts are enhanced when the concentration of chloride is less than $10^{-4} \mathrm{M}$ (Figure 3c). In the case of both branches, more intense dissolution is expected due to the formation of soluble chloride complexes (anodic case) which can also trigger dissolution in the cathodic scan once oxides are reduced [45]. Additionally, in the cathodic counterpart, increased dissolution in the case of chlorides due to inhibited re-deposition of Au ions should be considered as well [32]. Namely, two characteristics should be taken into account: (a) the surface of the Au electrode is covered/passivated with adsorbed chloride species hence Au re-deposition is significantly obstructed causing a change in the dissolution mechanism; (b) dissolved Au species are present as chloride complexes the reduction of which is thermodynamically less favored in comparison to Au aqua complexes (see equations above), and therefore these relatively stable complexes are washed away before being reduced. A similar effect was also observed on Pt-based electrodes [32,49]. However, in the presence of $10^{-4} \mathrm{M} \mathrm{Cl}^{-}$cathodic dissolution profile is significantly less intense than in the case of lower concentrations of $\mathrm{Cl}^{-}$(Figure 3c). This directly confirms the inhibition of Au oxide formation in the presence of chlorides (substantially 
less "oxide-induced" dissolution). This is more clearly observed if CVs and Au dissolution profiles are simultaneously compared (Figure 3d).

\subsection{Electrochemical Dissolution of Au Nanoparticles}

\subsubsection{Dissolution of Au Nanoparticles in the Absence of Chlorides}

Dissolution in the case of metallic polycrystalline disks is expected to be different in comparison to nanoparticulate electrodes due to the so-called particle size effect [50-53]. Such findings originate especially from extensive research on Pt-based electrodes where the thermodynamic stability of the nanoparticles is increasing with their size. It is well known that with decreasing size of nanoparticles the ratio of the surface atoms at terraces to that in step edges and kinks becomes smaller. Therefore, with this decrease of the coordination number the Nernst equilibrium potential becomes more negative, which should result in a higher dissolution from surface defect sites at lower potentials [53-56]. The same EFC-ICP-MS experimental protocol as in the case of Au polycrystalline disk was performed in the case of carbon supported Au nanoparticles $(\mathrm{Au} / \mathrm{C})$. By normalizing dissolution profiles on the real Au surface area (for details see Experimental) intrinsic dissolution differences between Au nanoparticles and $\mathrm{Au}$ polycrystalline disc can be investigated (Figure $4 a, b$ ). A rather unusual trend is noticed as both analogues show very similar dissolution when cycling till UPL 1.4 V. Even more interesting is that when cycling until 1.6 V Au nanoparticles show much larger corrosion resistance in comparison to the Au disk (Figure 4b). According to thermodynamic predictions, a reverse trend would be expected, namely Au nanoparticles should dissolve more. However, other aspects of electrode/electrolyte interaction have to be considered as well such as the formation of surface hydroxides and oxides. These passivate the electrode surface. The passivation effect is stronger when the coordination number of surface atoms is decreased. Hence at the same potential, the surface coverage with $\mathrm{OH}$ increases with decreases in the particle size [57]. This should result in less intense dissolution in the case of Au nanoparticles when compared to Au disk. We again note that the dissolution under UPL in the case of Figure 4 is consisted of anodic and cathodic part. Less intensive anodic dissolution in the case of Au nanoparticles is in line with more effective passivation in the latter. However, in order to explain a trend regarding cathodic dissolution, one should take into account that Au nanoparticles are embedded in carbon support. Hence, the effective thickness of the electrode is greater than in the case of Au disk. This could change the dissolution pattern via the following two effects: (i) as mentioned above, the cathodic dissolution is partially governed by re-deposition of dissolved ions. In the case of Au nanoparticles diffusion paths of dissolved cations are longer in comparison to Au disc since nanoparticles are supported on a thin layer of high surface area carbon (approximately $1 \mu \mathrm{m}$ thick). Therefore statistically, Au ions are more likely to re-deposit [58]. (ii) Due to the porosity of the electrode layer in the case of the $\mathrm{Au} / \mathrm{C}$ analogue the concentration of dissolved $\mathrm{Au}$ ions within the electrode layer is probably higher than in the case of the Au disk. This can cause an oversaturation within the electrode layer sooner which would explain why anodic dissolution is less intense in the case of Au nanoparticles. Both effects (i and ii) have already been reported for Pt/C catalyst [58].

\subsubsection{Dissolution of Au Nanoparticles in the Presence of Chlorides}

The explanation above is further supported by investigating the dissolution of $\mathrm{Au} / \mathrm{C}$ analogue in the presence of chlorides. In contrast to the observation in the case of Au disk, dissolution in the case of $\mathrm{Au} / \mathrm{C}$ is not increasing with increasing concentration of chlorides (Figure $4 \mathrm{c}, \mathrm{d}$ ). Surprisingly, until $10^{-4} \mathrm{M} \mathrm{Cl}^{-}$ $\mathrm{Au}$ dissolution is decreasing with increasing $\mathrm{Cl}^{-}$concentration. This proves that the passivation effect of chlorides causes less oxide-induced dissolution. Furthermore, due to the porosity of the carbon support, dissolved Au species can undergo re-deposition as mentioned above. These findings are especially 
important for the corrosion protection or resistance of devices since gold nanoparticles embedded in high surface area carbon exhibit improved stability over the polycrystalline Au surface. Coupled with the fact that a much lower amount of gold is needed to cover surfaces, this should be explored in anti-corrosion coatings applications.
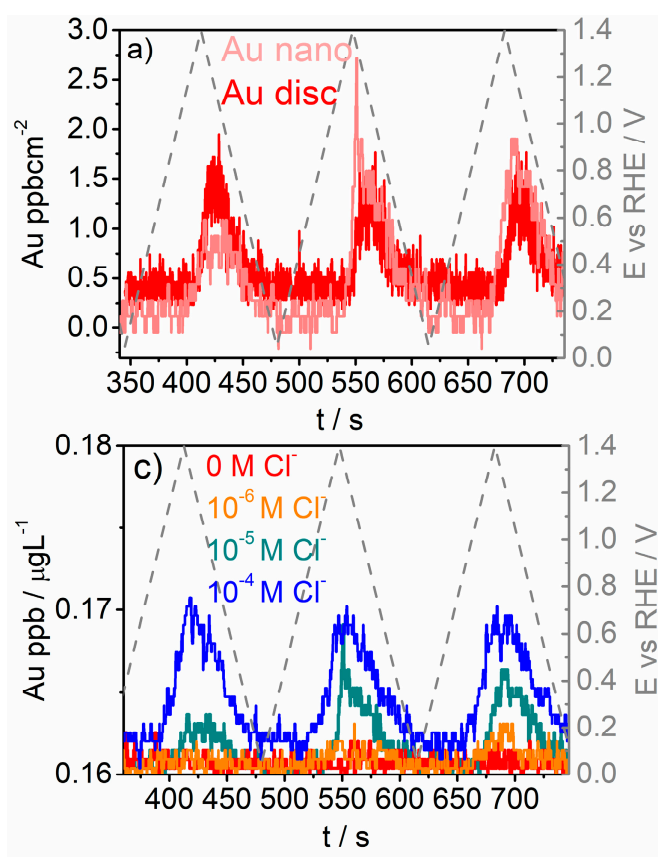
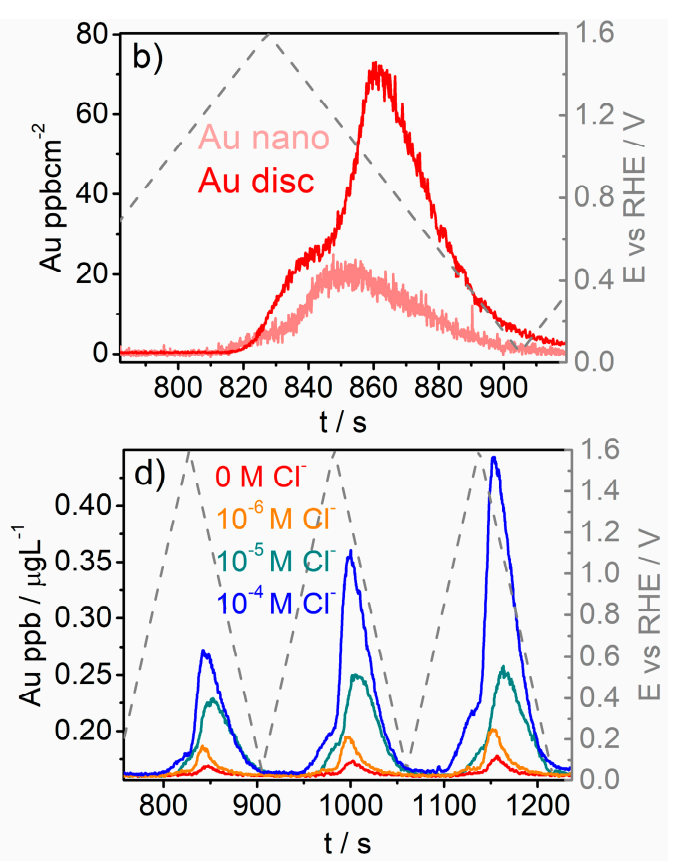

Figure 4. EFC-ICP-MS measurements of Au dissolution from Au nanoparticles in the absence $(\mathbf{a}, \mathbf{b})$ and presence of chlorides $(\mathbf{c}, \mathbf{d})$ during potentiodynamic cycles $\left(20 \mathrm{mV} \cdot \mathrm{s}^{-1}, 0.05-1.4\right.$ or $\left.1.6 \mathrm{~V}_{\mathrm{RHE}}\right)$.

\section{Conclusions}

An on-line and downstream analytical tool, electrochemical flow cell connected to an inductively coupled plasma mass spectrometer, was used to study dissolution of Au based materials in the presence of chlorides. A comparative study of polycrystalline and nanostructured Au-based electrodes provided for novel insights into the corrosion process. Namely, polycrystalline Au dissolution mechanism is altered once (i) the chloride concentration $\left(>10^{-4} \mathrm{M}\right)$ and (ii) the potential are sufficiently high $(<1.6 \mathrm{~V} \mathrm{vs}$. RHE). In this case, cathodic dissolution is inhibited due to the suppression of oxide-driven dissolution on account of chloride-induced passivation of the Au surface. In the case of Au nanoparticles, besides the effect of particle size also the effect of carbon support should be taken into account. More specifically, due to the higher effective thickness and porous morphology, the Au dissolution mechanism is altered and the overall

dissolution decreases. Therefore, nanostructured gold should be considered as an option in anti-corrosion coating applications.

Author Contributions: Conceptualization, P.J. and N.H.; Methodology, P.J., M.M., E.G., M.Š., G.M., M.B. and F.R.-Z.; Validation, M.Š., and P.J.; Formal Analysis, M.M., E.G., M.Š., P.J., and F.R.-Z.; Investigation, P.J., and F.R.-Z.; Writing-Original Draft Preparation, P.J., F.R.-Z. and N.H; Writing-Review \& Editing, P.J., G.M. and N.H.

Funding: This research was funded by Slovenian Research Agency (ARRS) through Projects Z2-8161 and Z1-9165 and Project P1-0153.

Conflicts of Interest: The authors declare no conflict of interest. 


\section{References}

1. Hammer, B.; Norskov, J.K. Why gold is the noblest of all the metals. Nature 1995, 376, 238-240. [CrossRef]

2. Wittstock, A.; Zielasek, V.; Biener, J.; Friend, C.M.; Baumer, M. Nanoporous gold catalysts for selective gas-phase oxidative coupling of methanol at low temperature. Science 2010, 327, 319-322. [CrossRef] [PubMed]

3. Cherevko, S.; Chung, C.-H. Gold nanowire array electrode for non-enzymatic voltammetric and amperometric glucose detection. Sens. Actuators B Chem. 2009, 142, 216-223. [CrossRef]

4. Segura, R.; Pizarro, J.; Díaz, K.; Placencio, A.; Godoy, F.; Pino, E.; Recio, F. Development of electrochemical sensors for the determination of selenium using gold nanoparticles modified electrodes. Sens. Actuators B Chem. 2015, 220, 263-269. [CrossRef]

5. Cherevko, S.; Kulyk, N.; Chung, C. Nanoporous Pt@ $\mathrm{Au}_{x} \mathrm{Cu}_{100-x}$ by hydrogen evolution assisted electrodeposition of $\mathrm{Au}_{x} \mathrm{Cu}_{100-x}$ and galvanic replacement of $\mathrm{Cu}$ with Pt: Electrocatalytic properties. Langmuir 2012, 28, 3306-3315. [CrossRef] [PubMed]

6. Hartl, K.; Mayrhofer, K.J.J.J.; Lopez, M.; Goia, D.; Arenz, M. AuPt core-shell nanocatalysts with bulk Pt activity. Electrochem. Commun. 2010, 12, 1487-1489. [CrossRef]

7. Gatalo, M.; Jovanovič, P.; Polymeros, G.; Grote, J.-P.; Pavlišič, A.; Ruiz-Zepeda, F.; Šelih, V.S.; Šala, M.; Hočevar, S.; Bele, M.; et al. Positive effect of surface doping with Au on the stability of Pt-based electrocatalysts. ACS Catal. 2016, 6, 1630-1634. [CrossRef]

8. Selvaganesh, S.V.; Selvarani, G.; Sridhar, P.; Pitchumani, S.; Shukla, A.K. Durable electrocatalytic-activity of Pt-Au/C cathode in PEMFCs. Phys. Chem. Chem. Phys. 2011, 13, 12623-12634. [CrossRef] [PubMed]

9. Sun, X.; Dongguo, L.; Yong, D.; Zhu, W.; Shaojun, G.; Zhong, L.W.; Sun, S. Core/shell Au/CuPt nanoparticles and their dual electrocatalysis for both reduction and oxidation reactions. J. Am. Chem. Soc. 2014, 136, 5745-5749. [CrossRef] [PubMed]

10. Zhang, J.; Sasaki, K.; Sutter, E.; Adzic, R.R. Stabilization of platinum oxygen-reduction electrocatalysts using gold clusters. Science 2007, 315, 220-222. [CrossRef] [PubMed]

11. Zhao, D.; Xu, B.-Q. Platinum covering of gold nanoparticles for utilization enhancement of Pt in electrocatalysts. Phys. Chem. Chem. Phys. 2006, 8, 5106-5114. [CrossRef] [PubMed]

12. Schubert, M.; Kahlich, M.; Gasteiger, H.; Behm, R. Correlation between CO surface coverage and selectivity/kinetics for the preferential $\mathrm{CO}$ oxidation over $\mathrm{Pt} / \gamma-\mathrm{Al}_{2} \mathrm{O}_{3}$ and $\mathrm{Au} / \alpha-\mathrm{Fe}_{2} \mathrm{O}_{3}$ : An in-situ DRIFTS study. J. Power Sources 1999, 84, 175-182. [CrossRef]

13. Fujita, T.; Guan, P.; McKenna, K.; Lang, X.; Hirata, A.; Zhang, L.; Tokunaga, T.; Arai, S.; Yamamoto, Y.; Tanaka, N.; et al. Atomic origins of the high catalytic activity of nanoporous gold. Nat. Mater. 2012, 11, 775-780. [CrossRef] [PubMed]

14. Diaz-Morales, O.; Calle-Vallejo, F.; de Munck, C.; Koper, M.T.M. Electrochemical water splitting by gold: Evidence for an oxide decomposition mechanism. Chem. Sci. 2013, 4, 2334-2343. [CrossRef]

15. Jeyabharathi, C.; Hasse, U.; Ahrens, P.; Scholz, F. Oxygen electroreduction on polycrystalline gold electrodes and on gold nanoparticle-modified glassy carbon electrodes. J. Solid State Electrochem. 2014, 18, 3299-3306. [CrossRef]

16. Määttänen, A.; Ihalainen, P.; Pulkkinen, P.; Wang, S.; Tenhu, H.; Peltonen, J. Inkjet-printed gold electrodes on paper: Characterization and functionalization. ACS Appl. Mater. Interfaces 2012, 4, 955-964. [CrossRef] [PubMed]

17. Wang, D.; Zhang, Y.; Lu, X.; Ma, Z.; Xie, C.; Zheng, Z. Chemical formation of soft metal electrodes for flexible and wearable electronics. Chem. Soc. Rev. 2018, 47, 4611-4641. [CrossRef] [PubMed]

18. Shariq, M.; Friedrich, B.; Budic, B.; Hodnik, N.; Ruiz-Zepeda, F.; Majerič, P.; Rudolf, R. Successful synthesis of gold nanoparticles through ultrasonic spray pyrolysis from a gold(III) nitrate precursor and Their interaction with a high electron beam. ChemistryOpen 2018, 7, 533-542. [CrossRef] [PubMed]

19. Harsányi, G. Irregular effect of chloride impurities on migration failure reliability: Contradictions or understandable? Microelectron. Reliab. 1999, 39, 1407-1411. [CrossRef]

20. Frankenthal, R.P. The anodic corrosion of gold in concentrated chloride solutions. J. Electrochem. Soc. 1982, 129, 1192-1196. [CrossRef] 
21. Gaur, J.N.; Schmid, G.M. Electrochemical behavior of gold in acidic chloride solutions. J. Electroanal. Chem. Interfacial Electrochem. 1970, 24, 279-286. [CrossRef]

22. Klemm, S.O.; Topalov, A.A.; Laska, C.A.; Mayrhofer, K.J.J. Coupling of a high throughput microelectrochemical cell with online multielemental trace analysis by ICP-MS. Electrochem. Commun. 2011, 13, 1533-1535. [CrossRef]

23. Cherevko, S.; Topalov, A.A.; Katsounaros, I.; Mayrhofer, K.J.J. Electrochemical dissolution of gold in acidic medium. Electrochem. Commun. 2013, 28, 44-46. [CrossRef]

24. Topalov, A.A.; Katsounaros, I.; Auinger, M.; Cherevko, S.; Meier, J.C.; Klemm, S.O.; Mayrhofer, K.J.J. Dissolution of platinum: Limits for the deployment of electrochemical energy conversion? Angew. Chem. Int. Ed. Engl. 2012, 51, 12613-12615. [CrossRef] [PubMed]

25. Schuppert, A.K.; Topalov, A.A.; Katsounaros, I.; Klemm, S.O.; Mayrhofer, K.J.J. A scanning flow cell system for fully automated screening of electrocatalyst materials. J. Electrochem. Soc. 2012, 159, F670-F675. [CrossRef]

26. Cherevko, S.; Zeradjanin, A.R.; Topalov, A.A.; Kulyk, N.; Katsounaros, I.; Mayrhofer, K.J.J. Dissolution of noble metals during oxygen evolution in acidic media. ChemCatChem. 2014, 6, 2219-2223. [CrossRef]

27. Cherevko, S.; Topalov, A.A.; Zeradjanin, A.R.; Katsounaros, I.; Mayrhofer, K.J.J. Gold dissolution: Towards understanding of noble metal corrosion. RSC Adv. 2013, 3, 16516-16527. [CrossRef]

28. Jovanovič, P.; Šelih, V.S.; Šala, M.; Hočevar, S.; Ruiz-Zepeda, F.; Hodnik, N.; Bele, M.; Gaberšček, M. Potentiodynamic dissolution study of PtRu/C electrocatalyst in the presence of methanol. Electrochim. Acta 2016, 211, 851-859. [CrossRef]

29. Hodnik, N.; Jovanovič, P.; Pavlišič, A.; Jozinović, B.; Zorko, M.; Bele, M.; Šelih, V.S.; Šala, M.; Hočevar, S.; Gaberšček, M. New insights into corrosion of ruthenium and ruthenium oxide nanoparticles in acidic media. J. Phys. Chem. C 2015, 119, 10140-10147. [CrossRef]

30. Jovanovič, P.; Šelih, V.S.; Šala, M.; Hočevar, S.B.; Pavlišič, A.; Gatalo, M.; Bele, M.; Ruiz-Zepeda, F.; Čekada, M.; Hodnik, N.; Gaberšček, M. Electrochemical in-situ dissolution study of structurally ordered, disordered and gold doped $\mathrm{PtCu}_{3}$ nanoparticles on carbon composites. J. Power Sources 2016, 327, 675-680. [CrossRef]

31. Jovanovič, P.; Pavlišič, A.; Šelih, V.S.; Šala, M.; Hodnik, N.; Bele, M.; Hočevar, S.; Gaberšček, M. New insight into platinum dissolution from nanoparticulate platinum-based electrocatalysts using highly sensitive in situ concentration measurements. ChemCatChem 2014, 6, 449-453. [CrossRef]

32. Pavlišič, A.; Jovanovič, P.; Šelih, V.S.; Šala, M.; Hodnik, N.; Hočevar, S.; Gaberšček, M. The influence of chloride impurities on Pt/C fuel cell catalyst corrosion. Chem. Commun. 2014, 50, 3732-3734. [CrossRef] [PubMed]

33. Nicol, M.J. The anodic behaviour of gold-Part II-Oxidation in alkaline solutions. Gold Bull. 1980, 13, 105-106. [CrossRef]

34. Cadle, S.H.; Bruckenstein, S. A ring-disk study of the effect of trace chloride ion on the anodic behavior of gold in $0.2 \mathrm{M} \mathrm{H}_{2} \mathrm{SO}_{4}$. J. Electroanal. Chem. Interfacial Electrochem. 1973, 48, 325-331. [CrossRef]

35. Nowicka, A.M.; Hasse, U.; Sievers, G.; Donten, M.; Stojek, Z.; Fletcher, S.; Scholz, F. Selective knockout of gold active sites. Angew. Chem. Int. Ed. 2010, 49, 3006-3009. [CrossRef] [PubMed]

36. Burke, L.D.; O'Mullane, A.P. Generation of active surface states of gold and the role of such states in electrocatalysis. J. Solid State Electrochem. 2000, 4, 285-297. [CrossRef]

37. Angerstein-Kozlowska, H.; Conway, B.E.; Hamelin, A.; Stoicoviciu, L. Elementary steps of electrochemical oxidation of single-crystal planes of $\mathrm{Au}-\mathrm{I}$. Chemical basis of processes involving geometry of anions and the electrode surfaces. Electrochim. Acta 1986, 31, 1051-1061. [CrossRef]

38. Conway, B.E. Electrochemical oxide film formation at noble metals as a surface-chemical process. Prog. Surf. Sci. 1995, 49, 331-452. [CrossRef]

39. Tian, M.; Pell, W.G.; Conway, B.E. Nanogravimetry study of the initial stages of anodic surface oxide film growth at $\mathrm{Au}$ in aqueous $\mathrm{HClO}_{4}$ and $\mathrm{H}_{2} \mathrm{SO}_{4}$ by means of EQCN. Electrochim. Acta 2003, 48, 2675-2689. [CrossRef]

40. Tremiliosi-Filho, G.; Dall'Antonia, L.H.; Jerkiewicz, G. Limit to extent of formation of the quasi-two-dimensional oxide state on Au electrodes. J. Electroanal. Chem. 1997, 422, 149-159. [CrossRef]

41. Jovanovič, P.; Šelih, V.S.; Šala, M.; Hodnik, N. In situ electrochemical dissolution of platinum and gold in organic-based solvent. Npj Mater. Degrad. 2018, 2, 9. [CrossRef] 
42. Pavlišič, A.; Jovanovič, P.; Šelih, V.S.; Šala, M.; Hodnik, N.; Gaberšček, M. Platinum dissolution and redeposition from Pt/C fuel cell electrocatalyst at potential cycling. J. Electrochem. Soc. 2018, 165, F3161-F3165. [CrossRef]

43. Jovanovič, P.; Ruiz-Zepeda, F.; Šala, M.; Hodnik, N. Atomic scale insights into electrochemical dissolution of Janus Pt-SnO 2 nanoparticles in the presence of ethanol in acidic media: An IL-STEM and EFC-ICP-MS study. J. Phys. Chem. C 2018, 122, 10050-10058. [CrossRef]

44. Topalov, A.A.; Cherevko, S.; Zeradjanin, A.R.; Meier, J.C.; Katsounaros, I.; Mayrhofer, K.J.J.; Josef, C. Towards a comprehensive understanding of platinum dissolution in acidic media. Chem. Sci. 2014, 5, 631-638. [CrossRef]

45. Kasian, O.; Kulyk, N.; Mingers, A.; Zeradjanin, A.R.; Mayrhofer, K.J.J.; Cherevko, S. Electrochemical dissolution of gold in presence of chloride and bromide traces studied by on-line electrochemical inductively coupled plasma mass spectrometry. Electrochim. Acta 2016, 222, 1056-1063. [CrossRef]

46. Cherevko, S.; Zeradjanin, A.R.; Keeley, G.P.; Mayrhofer, K.J.J. A comparative study on gold and platinum dissolution in acidic and alkaline media. J. Electrochem. Soc. 2014, 161, H822-H830. [CrossRef]

47. Ye, S.; Ishibashi, C.; Shimazu, K.; Uosaki, K. An in situ electrochemical quartz crystal microbalance study of the dissolution process of a gold electrode in perchloric acid solution containing chloride ion. J. Electrochem. Soc. 1998, 145, 1614-1623. [CrossRef]

48. Ye, S.; Ishibashi, C.; Uosaki, K. Anisotropic dissolution of an Au(111) electrode in perchloric acid solution containing chloride anion investigated by in situ STMThe important role of adsorbed chloride anion. Langmuir 1999, 15, 807-812. [CrossRef]

49. Geiger, S.; Cherevko, S.; Mayrhofer, K.J.J.J. Dissolution of platinum in presence of chloride traces. Electrochim. Acta 2015, 179, 24-31. [CrossRef]

50. Park, S.; Lee, J.-W.; Popov, B.N. A review of gas diffusion layer in PEM fuel cells: Materials and designs. Int. J. Hydrogen Energ. 2012, 37, 5850-5865. [CrossRef]

51. Kinoshita, K. Small-particle effects and structural considerations for electrocatalysis. In Modern Aspects of Electrochemistry; Springer: Boston, MA, USA, 1982.

52. Maillard, F.; Pronkin, S.; Savinova, E.R. Size effects in electrocatalysis of fuel cell reactions on supported metal nanoparticles. In Fuel Cell Catalysis: A Surface Science Approach; John Wiley \& Sons, Inc.: Hoboken, NJ, USA, 2008.

53. Lorenz, W.J.; Staikov, G.; Schindler, W.; Wiesbeck, W. The role of low-dimensional systems in electrochemical phase formation and dissolution processes. J. Electrochem. Soc. 2002, 149, K47-K59. [CrossRef]

54. Plieth, W.J. Electrochemical properties of small clusters of metal atoms and their role in surface enhanced Raman scattering. J. Phys. Chem. 1982, 86, 3166-3170. [CrossRef]

55. Tang, L.; Han, B.; Persson, K.; Friesen, C.; He, T.; Sieradzki, K.; Ceder, G. Electrochemical stability of nanometer-scale Pt particles in acidic environments. J. Am. Chem. Soc. 2010, 132, 596-600. [CrossRef] [PubMed]

56. Tang, L.; Li, X.; Cammarata, R.C.; Friesen, C.; Sieradzki, K. Electrochemical stability of elemental metal nanoparticles. J. Am. Chem. Soc. 2010, 132, 11722-11726. [CrossRef] [PubMed]

57. Mayrhofer, K.J.J.; Blizanac, B.B.; Arenz, M.; Stamenkovic, V.R.; Ross, P.N.; Markovic, N.M. The impact of geometric and surface electronic properties of Pt-catalysts on the particle size effect in electrocatalysis. J. Phys. Chem. B 2005, 109, 14433-14440. [CrossRef] [PubMed]

58. Jovanovič, P.; Petek, U.; Hodnik, N.; Ruiz-Zepeda, F.; Gatalo, M.; Šala, M.; Šelih, V.S.; Fellinger, T.P.; Gaberšček, M. Importance of non-intrinsic platinum dissolution in Pt/C composite fuel cell catalysts. Phys. Chem. Chem. Phys. 2017, 19, 21446-21452. [CrossRef] [PubMed]

(C) 2018 by the authors. Licensee MDPI, Basel, Switzerland. This article is an open access article distributed under the terms and conditions of the Creative Commons Attribution (CC BY) license (http:/ / creativecommons.org/licenses/by/4.0/). 